\title{
Efektivitas Agen Pendeplesi GSH pada Sitotoksisitas Cisplatin terhadap Sel Kanker: Systematic Literature Review
}

\section{Effectivity of GSH Depletion Agent for Cytotoxicity of Cisplatin on Cancer Cell: Systematic Literature Review}

\author{
Elisa Tri Oktaviyana, Wahyu Utami* \\ Fakultas Farmasi, Universitas Muhammadiyah Surakarta, \\ Jl. Ahmad Yani, Pabelan, Surakarta 57162, Indonesia \\ *E-mail: Wahyu.Utami@ums.ac.id
}

Received: 10 November 2021; Accepted: 19 Desember 2021; Published: 31 Desember 2021

\begin{abstract}
Abstrak
Cisplatin adalah salah satu agen kemoterapi untuk terapi kanker paru-paru, kanker ovarium, kanker saluran pencernaan, kanker payudara, dan kanker kepala dan leher. Namun, peranan cisplatin ternyata tidak selalu memberikan efek optimal dikarenakan sering munculnya fenomena resistensi sel kanker terhadap cisplatin. Kondisi resistensi terjadi salah satunya karena terbentuknya metabolit inaktif dari reaksi konjugasi antara cisplatin dengan GSH. Dengan demikian, glutation (GSH) memiliki peranan penting dalam pengendalian resistensi cisplatin. Penelitian ini bertujuan untuk mengkaji penggunaan kombinasi cisplatin dengan agen pendeplesi glutation (GSH) sebagai penunjang aktivitas sitotoksik cisplatin di beberapa jenis sel kanker secara in vitro. Penelitian ini disusun menggunakan metode systematic literature review. Penelusuran pustaka dilakukan pada dua database jurnal internasional terakreditasi yaitu PubMed dan Science Direct dengan interval tahun publikasi 2011-2020. Dari 10 jurnal yang terpilih, menunjukkan bahwa penggunaan agen pendeplesi GSH (BSO, DPP-23, hederagenin, $\alpha$-hederin, micheliolide, phenylethyl isothiocyanate (PEITC), artesunate, dan ekstrak fucoidan) mampu meningkatkan efek sitotoksik pada cisplatin. Hal ini dianalisis berdasarkan data jumlah GSH sel terukur dan jumlah sel hidup (\% viabilitas sel) yang memberikan hasil penurunan signifikan. Hasil dari penelitian ini diharapkan mampu memberikan informasi untuk pengembangan agen terapi pada cisplatin sebagai kemoterapi.
\end{abstract}

Kata Kunci: Kanker, in vitro, cisplatin, agen pendeplesi GSH.

\begin{abstract}
Cisplatin is one of chemotherapy agent for lung, ovarian, gastric, breast, and head-neck cancer. However, in the fact, the role of cisplatin does not always provide an optimal effect because it often appears cancer cell become resistance to cisplatin. This resistance condition occurs partly due to the inactive metabolite cause of conjugation reaction between cisplatin and GSH in cancer cells. Therefore, gluthathione (GSH) has an important role in controlling cisplatin resistance. This study aims to analyze some combination of cisplatin and the depletion agent of gluthathione (GSH) as a support for cisplatin activity in several types of cancer cells within in vitro scope. This study was prepared using systematic literature review method. Library search were carried out on two accredited international journals databases, namely PubMed and Science Direct with interval years of publication in 2011-2020. From 10 selected journals, it was shown that the use of GSH depletion agents (BSO, DPP-23, hederagenin, $\alpha$-hederin, micheliolide, phenylethyl isotyocianate (PEITC), artesunate, and fucoidan extract) could enhance the cytotoxic effect of cisplatin. This was analyzed based on data of the number measured GSH cells and the number of living cells (\% cell viability) which gave a significant decrease. The result of research are expected to be able to provide information for the development of therapeutic agents on cisplatin as chemotherapy agent.
\end{abstract}

Keywords: Cancer, in vitro, cisplatin, GSH depletion agent. 


\section{PENDAHULUAN}

Cisplatin, cis-diammichloroplatinum(II), adalah senyawa segi empat planar platinum yang merupakan salah satu agen kemoterapi potensial dalam terapi antikanker. Secara klinis, aktivitas antikanker pada cisplatin bekerja pada berbagai jenis kanker antara lain kanker paru-paru, kanker ovarium, kanker karsinoma, kanker payudara, dan kanker otak. Ada beberapa jalur mekanisme molekul cisplatin dalam mencapai efek terapi yaitu melalui induksi oxidative stress, modulasi sinyal $\mathrm{Ca}$, induksi sel apoptosis, protein kinase $\mathrm{C}$, mitogen-activated protein kinase (MAPK), Jun amino- terminal kinase (JNK), p38 mitogen-activated protein kinase (MAPK), AKT (serin/treonin kinase), perusakan sinyal DNA, dan kerusakan DNA p53 (Dasari and Bernard Tchounwou, 2014). Cisplatin memiliki bentuk stereoisomer geometri yaitu transplatin. Berbeda dengan cisplatin, transplatin justru tidak memiliki aktivitas yang baik dalam menghambat sel kanker. Hal ini disebabkan adanya hambatan sterik yang berfrekuensi tinggi pada untaian DNA lokal menyebabkan transplatin tidak mampu membentuk ikatan 1,2 intrastrand, sebagaimana pada cisplatin, sehingga aktivitas antikanker yang baik lebih dimiliki oleh cisplatin (Komeda, 2019).

Cisplatin sering dikombinasikan dengan agen kemoterapi, radioterapi, dan immunoterapi untuk menunjang aksi terapinya (Ghosh, 2019). Namun dalam ketercapaian efek terapi, ternyata cisplatin sering memberikan hasil yang tidak sepenuhnya optimal, sebab ditemukan fenomena resistensi intrinsik yang sering terjadi dalam pengobatan.

Resistensi ini menjadi salah satu permasalahan utama ketika sel kanker tidak merespon terapi dari cisplatin, sehingga akan menyebabkan terjadinya kegagalan kemoterapi. Mekanisme intraselular yang terlibat dalam kasus resistensi sel kanker terhadap cisplatin disebabkan oleh peningkatan detoksifikasi obat oleh gluthathione (GSH) atau metallothionein (makromoleul sulfur yang terlibat dalam detoksifikasi ion logam berat) yang kemudian memicu menurunnya akumulasi cisplatin di dalam tubuh dan mengakibatkan penurunan apoptosis pada sel kanker (Florea and Büsselberg, 2011). Pada reaksi detoksifikasi, konjugat yang terbentuk dari ikatan konjugasi platinum-GSH akan membentuk suatu metabolit inaktif yang membuat struktur obat menjadi lebih polar. Oleh karena itu, cisplatin akan lebih mudah diekskresikan melalui ginjal dan akibatnya kadar cisplatin di dalam tubuh akan menurun (Chan et al., 2019).

Keterlibatan peranan GSH yang menyebabkan terjadinya reaksi detoksifikasi tersebut, menjadikan penggunaan agen pendeplesi GSH menjadi salah satu pendekatan yang dapat digunakan untuk mengurangi resistensi sel kanker terhadap cisplatin, yaitu dengan menurunkan kadar GSH intraseluler pada sel kanker. Menurut penelitian yang dilakukan Sato et al (2004), agen pendeplesi GSH menginisiasi pembentukan apoptosom. Selain itu, agen pendeplesi GSH juga memodulasi pori transisi permeabilitas yang memicu pada kematian sel (Tewari-Singh et al., 2011). Agen pendeplesi GSH terbukti mampu menjadi alternatif dalam mencegah terjadinya resistensi sel kanker terhadap cisplatin. Oleh karena itu, penelitian ini dilakukan untuk mengkaji penggunaan agen pendeplesi GSH dalam aktivitas sitotoksik cisplatin di beberapa jenis sel kanker secara in vitro.

\section{METODE PENELITIAN}

Penelitian ini menggunakan studi kepustakaan berupa Systematic Literature Review yang dilakukan dengan menggunakan ketersediaan literatur yang ada dan masih relevan. Strategi pencarian pustaka dilakukan menggunakan dua jenis database internasional bereputasi yaitu PubMed dan Science Direct. Teknik pencarian yang digunakan ialah Boolean search engine menggunakan 12 kata kunci (Gambar 1). Pustaka yang dicari adalah kategori jurnal yang dipublikasikan dalam interval tahun 2011-2020 berbahasa Inggris yang tersedia dalam bentuk free full text dan open access. 
Dua belas buah kata kunci yang digunakan menghasilkan 250 pustaka. Jurnal yang telah diperoleh dari kedua database diorganisir melalui penyeleksian jurnal berdasarkan kriteria inklusi dan eksklusi. Penyeleksian dilakukan dengan beberapa tahap yang digambarkan pada diagram (Gambar 2). Pada

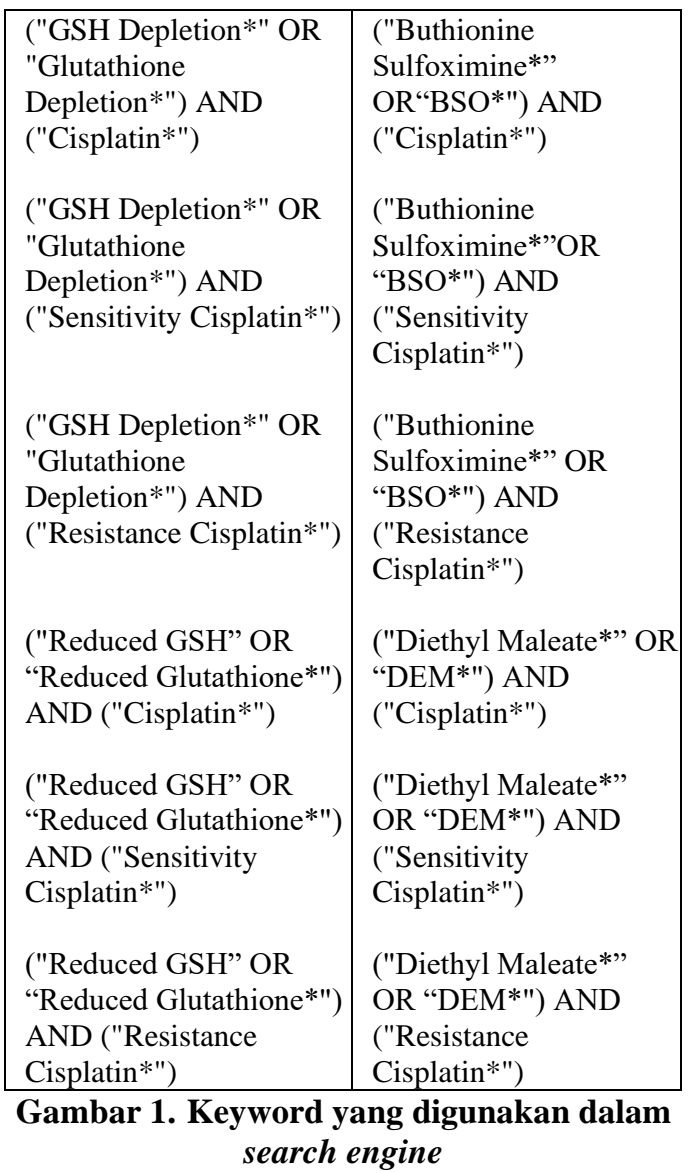

tahap pertama, dilakukan proses pengecekan duplikasi pada judul. Sebanyak 159 jurnal yang lolos pengecekan, kemudian dilanjutkan skrinning abstrak dan isi. Selanjutnya diperoleh 32 jurnal yang termasuk ke dalam penelitian lingkup in vitro, penelitian sitotoksik, dan memuat informasi seputar resitensi cisplatin serta peran agen pendeplesi GSH. Kemudian, dilanjutkan tahap quality assesment yang dilakukan dengan tujuan untuk menganalisis terkait kelengkapan data dari masing-masing jurnal sehingga diperoleh 10 jurnal terpilih.

\section{HASIL DAN PEMBAHASAN}

Terdapat 8 (delapan) jenis agen pendeplesi GSH yang telah diteliti aktivitas sitotoksiknya pada kasus resistensi sel kanker terhadap cisplatin antara lain buthionine sulfoximine (BSO), $\alpha$-hederin, micheliolide (MCL), DPP23, hederagenin, phenylethyl isothiocyanate (PEITC), artesunat, dan ekstrak fucoidan.

\section{Mekanisme Penurunan GSH Oleh Masing- Masing Agen Pendeplesi GSH}

Beberapa agen pendeplesi GSH memiliki mekanisme yang berbeda dalam menurunkan nilai GSH intraseluler sel kanker (Tabel 1). Penggunaan agen pendeplesi GSH pada sel kanker saluran empedu telah dilakukan dalam penelitian Li, Yin, et al (2016) dengan menggunakan buthionine sulfoximine (BSO). Perhitungan total GSH sel dilakukan menggunakan DTNB-GSSG recycling assay dengan waktu inkubasi selama 24 jam. Penelitian sebelumnya, Benedetti et al (2011) juga melakukan penelitian menggunakan BSO pada jenis sel kanker yang berbeda. Sel kanker yang digunakan adalah sel kanker ovarium. Berdasarkan penelitian yang telah dilakukan, Benedetti et al (2011) dan Li, Yin, et al (2016) menyebutkan bahwa BSO bekerja dengan menghambat enzim $\gamma$-glutamyl cystein synthetase (GCS) yang kemudian dapat memicu apoptosis pada sel kanker saluran empedu dan kanker ovarium. Enzim $\gamma$ glutamyl cystein synthetase (GCS) atau disebut juga enzim glutamate cysteine ligase (GCL) merupakan katalis laju biosintesis GSH sel.

Biosintesis GSH diawali dengan ikatan pada sistein dengan suatu peptida yang menghasilkan $\gamma$ glutamyl cystein dengan katalis enzim GCL. Sehingga dengan adanya penghambatan pada enzim GCL, tahap awal biosintesis GSH akan terhambat dan menyebabkan adanya penurunan produksi GSH intraseluler (Yuniastuti, 2010). Pada penelitian Li, Yin, et al (2016), selisih penurunan GSH sel sebesar $85 \%$. Li, Yin, et al (2016) juga menunjukkan bahwa BSO mampu menurunkan jumlah GSH intraseluler secara signifikan $(\mathrm{p}=0,0321)$ serta menurunkan nilai 


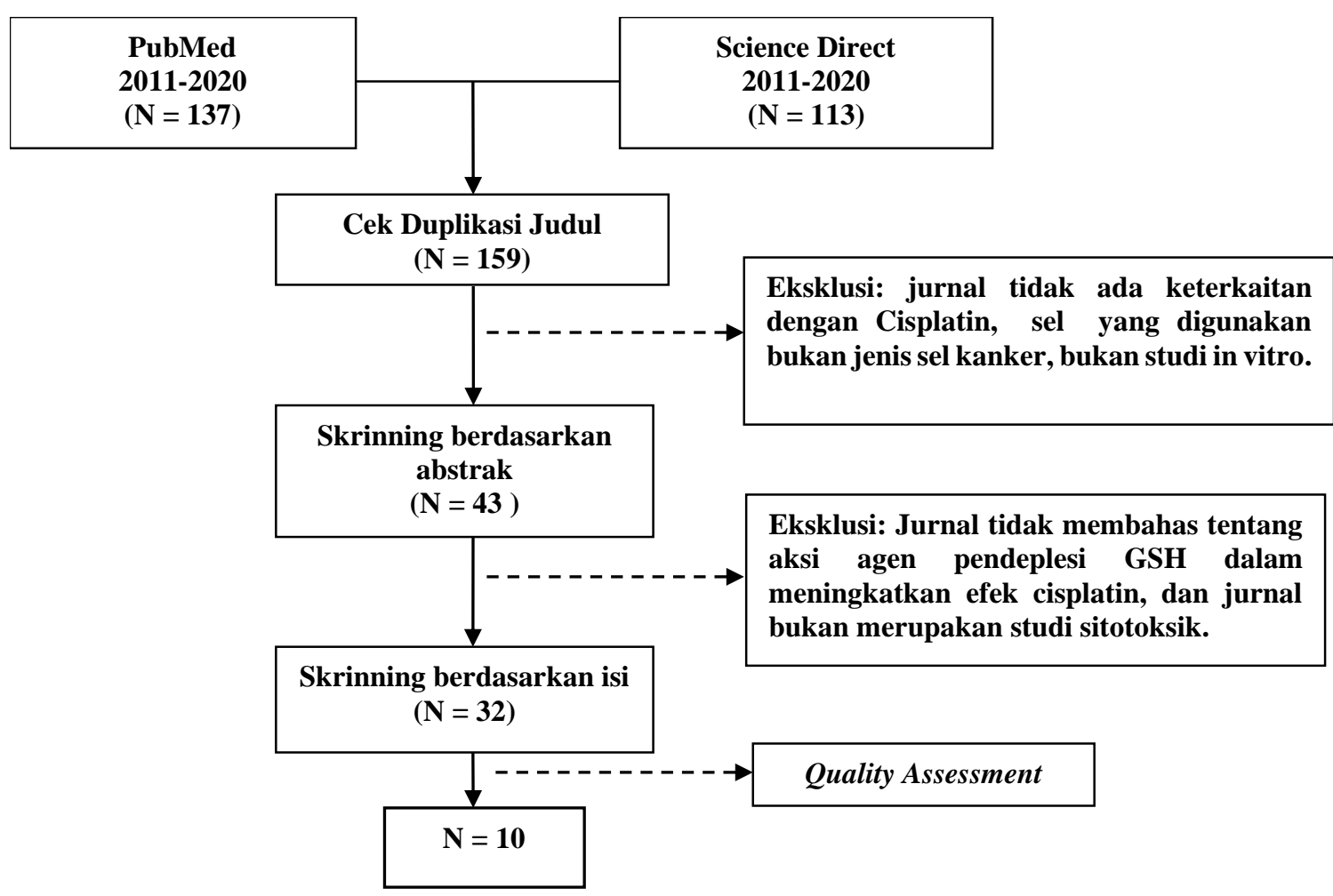

Gambar 2. Tahapan Seleksi Jurnal

rasio GSH/GSSG

tereduksi/glutation teroksidasi) yang mencerminkan keadaan redoks di dalam sel. Semakin kecil nilai rasio GSH/GSSG, maka jumlah GSH sel yang terbentuk akan semakin menurun tergantung pada waktu yang dibutuhkan saat perlakuan. Selanjutnya, pada penelitian Benedetti et al (2011) tidak dilakukan perhitungan GSH intraseluler.

Penelitian terhadap sel kanker saluran empedu lebih lanjut dilakukan oleh Li, Zhan, et al (2016) menggunakan phenylethyl isothiocyanate (PEITC) sebagai agen pendeplesi GSH dengan colorimetric microplate assay kit. Perlakuan diberikan dalam waktu inkubasi selama 1 jam. Li, Zhan, et al (2016) tidak menjelaskan terkait mekanisme penurunan GSH sel.

Kim et al (2016) meneliti aktivitas DPP-23 (konjugat polifenol) sebagai agen pendeplesi GSH dalam meningkatkan sensitivitas sel kanker kepala dan leher. Total jumlah GSH dibaca menggunakan colometric detection kit dan dihasilkan penurunan sebesar $12 \%$ dari kontrol GSH dalam waktu perlakuan selama 3 jam. Menurut Kim et al (2016), aktivitas penurunan GSH intraseluler pada sel kanker kepala dan leher (sel HNC) disebabkan dikarenakan penghambatan jalur Nrf2 melalui transkripsi ARE. p53 yang sebelumnya berperan sebagai penginduksi ekspresi Nrf2 sel, namun dengan adanya DPP-23, transkripsi ARE tidak akan terjadi kemudian memicu penurunan GSH dan kenaikan GSSG intrasel. Mekanisme yang sama juga terjadi pada penelitian Kim et al (2017) tentang pengaruh hederagenin terhadap resistansi cisplatin pada sel kanker kepala dan leher (sel HNC) dan menjelaskan bahwa hederagenin dapat memicu apoptosis melalui penghambatan jalur antioksidan sel yaitu penghambatan jalur Nrf2-ARE. Penghambatan ini dilihat dari hasil immunofluoresence staining assay. $\mathrm{Nrf} 2$ merupakan faktor transkripsi yang diekspresikan oleh Keap1 dan berperan dalam regulasi persinyalan redoks dalam sel. Jumlah GSH terukur sangat memengaruhi jalur apoptosis. Semakin kecil jumlah GSH sel yang terbentuk, maka tingkat ROS akan 
semakin tinggi. Dengan tingkat ROS yang semakin tinggi, kemampuan dalam memicu apoptosis sel pun akan semakin tinggi, sehingga dapat menurunkan nilai persentase viabilitas sel (Shelly C.Lu, 2014). agen pendeplesi GSH. Hal ini dikarenakan data penurunan yang diperoleh dari setiap jenis agen pendeplesi GSH dan jenis sel memiliki ketidaksamaan kondisi perlakuan seperti konsentrasi ciplatin, konsentrasi agen

Tabel 1. Jenis Agen Pendeplesi GSH beserta Mekanisme

\begin{tabular}{|c|c|c|c|c|}
\hline No & $\begin{array}{l}\text { Agen Pendeplesi } \\
\text { GSH }\end{array}$ & Sel kanker & $\begin{array}{l}\text { Mekanisme } \\
\text { penurunan GSH }\end{array}$ & Pustaka \\
\hline 1. & $\begin{array}{l}\text { Buthionine Sulfoximine } \\
\text { (BSO) }\end{array}$ & $\begin{array}{l}\text { Sel kanker saluran } \\
\text { empedu; sel kanker } \\
\text { ovarium }\end{array}$ & $\begin{array}{l}\text { Penghambatan } \\
\text { glutamylcystein } \\
\text { synthetase }\end{array}$ & $\begin{array}{l}\text { Benedetti et al, } \\
\text { 2011; Li, Yin, et } \\
\text { al,. } 2016\end{array}$ \\
\hline 2. & DPP-23 & $\begin{array}{l}\text { Sel kanker kepala } \\
\text { dan leher }\end{array}$ & $\begin{array}{l}\text { Penghambatan } N r f 2- \\
\text { ARE pathway }\end{array}$ & Kim et al, 2016 \\
\hline 3. & Hederagenin & $\begin{array}{l}\text { Sel kanker kepala } \\
\text { dan leher }\end{array}$ & $\begin{array}{l}\text { Penghambatan Nrf 2- } \\
\text { ARE pathway }\end{array}$ & Kim et al, 2017 \\
\hline 4. & $\alpha$-Hederin & Sel kanker pencernaan & N/A & $\begin{array}{l}\text { Deng et al, 2019; } \\
\text { Liu et al, } 2019\end{array}$ \\
\hline 5. & Micheliolide (MCL) & Sel kanker payudara & N/A & Jia et al, 2018 \\
\hline 6. & $\begin{array}{l}\text { Phenylethyl } \\
\text { isothiocyanate (PEITC) }\end{array}$ & $\begin{array}{l}\text { Sel kanker saluran } \\
\text { empedu }\end{array}$ & N/A & $\begin{array}{l}\text { Li, Zhan, et al,. } \\
2016\end{array}$ \\
\hline 7. & $\begin{array}{l}\text { Artesunat (malaria } \\
\text { drug) }\end{array}$ & $\begin{array}{l}\text { Sel kanker kepala } \\
\text { dan leher }\end{array}$ & N/A & Roh et al, 2017 \\
\hline 8. & Ekstrak Fucoidan & Sel kanker payudara & N/A & Zhang et al, 2013 \\
\hline
\end{tabular}

Tabel 2. Kemampuan Sitotoksik Kombinasi Cisplatin dan Agen Pendeplesi GSH (diadaptasi dari Benedetti et al (2011); Deng et al (2019); Jia et al (2018); Kim et al (2016); Kim et al (2017); Li, Yin, et al (2016); Li, Zhan, et al (2016); Liu et al (2019); Roh et al (2017); Zhang et al (2013)) Agen pendeplesi GSH Mekanisme apoptosis

\begin{tabular}{cc}
\hline Buthionine sulfoximine (BSO) & Mitochondrial pathway \\
$\alpha$-hederin & Mitochondrial pathway \\
Micheliolide (MCL) & Mitochondrial pathway \\
DPP-23 & Mitochondrial pathway \\
Hederagenin & Mitochondrial pathway \\
Phenylethyl isothiocyanate (PEITC) & Mitochondrial pathway \\
Ekstrak fucoidan & Extracellular Regulated Kinase pathway \\
\hline
\end{tabular}

Penelitian Deng et al (2019), Jia et al (2018), Liu et al (2019), dan Roh et al (2017) menunjukkan terjadinya penurunan GSH intraseluler pada sel kanker percernaan oleh $\alpha$ hederin. Namun, belum diteliti lebih lanjut mengenai mekanisme penurunannya.

Gambar 3 menunjukkan terjadinya penurunan kadar GSH intraseluler pada beberapa sel yang diberikan cisplatin bersamaan dengan agen pendeplesi GSH. Beberapa data yang diperoleh tidak dapat dilakukan interpretasi tingkat keefektifan pendeplesi GSH, dan waktu perlakuan yang berbeda.

Perlu diketahui bahwa setiap agen pendeplesi GSH memiliki siklus apoptosisnya masingmasing (Tabel 2). Pada penelitian penggunaan $\alpha$-hederin yang dilakukan oleh Deng et al (2019) dan Liu et al (2019), kombinasi ciplatin dengan $\alpha$-hederin memberikan aktivitas penghambatan proliferasi sel yang sangat besar setelah dibandingkan pada pemberian cisplatin tunggal terhadap sel kanker pencernaan. Deng et al (2019) memaparkan 

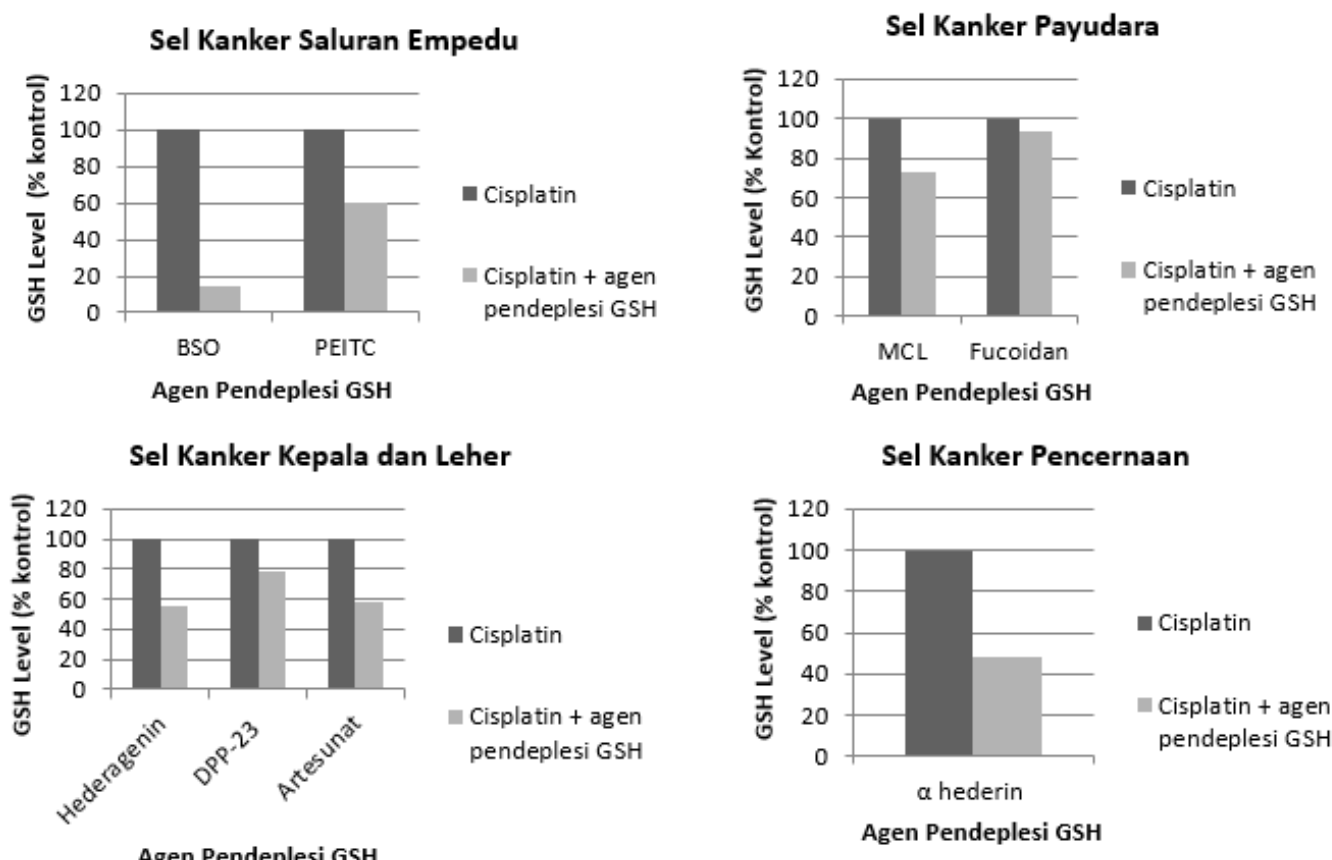

Agen Pendeplesi GSH

Agen Pendeplesi GSH

Gambar 3. Grafik Penurunan GSH Intraseluler pada Masing-Masing Sel Kanker (diadaptasi dari Benedetti et al (2011); Deng et al (2019); Jia et al (2018); Kim et al (2016); Kim et al (2017); Li, Yin, et al (2016); Li, Zhan, et al (2016); Liu et al (2019); Roh et al (2017); Zhang et al (2013))

penururunan nilai apoptosis sel hasil dari kombinasi cisplatin diduga karena Reactive Stress Oxidative (ROS) pada sel memainkan peran penting. ROS yang merusak mitokondria kemudian akan melepaskan cytochrome c ke sitoplasma yang berikatan dengan protein faktor yaitu apoptosis-related faktor 1 (Apaf1) pada dATP, yang akan memicu procaspase-9 berikatan dengan Apaf-1 membentuk apoptosom yang selanjutnya dapat mengaktifkan caspase-9. Lebih lanjut, pada penelitian yang dilakukan Liu et al (2019), $\alpha$-hederin dapat menurunkan pertumbuhan sel secara signifikan tergantung dosis dan waktu perlakuan. Mekanisme apoptosis yang diberikan pada kombinasi cisplatin dengan $\alpha$-hederin hampir sama dengan mekanisme apoptosis pada penelitian Deng et al (2019).

Penelitian pada sel kanker kepala dan leher, penurunan viabilitas sel diamati dengan penambahan kombinasi cisplatin dengan DPP-23 dan hederagenin. Dengan penambahan DPP-23, penelitian Kim et al (2016) menunjukkan bahwa selisih nilai viabilitas sel lebih sebesar $15 \%$. Selanjutnya, penelitian Kim et al (2017) menjelaskan bahwa dengan penggunaan hederagenin mampu menurunkan persen viabilitas sel sebesar $70 \%$. Penambahan konsentrasi hederagenin terbukti memberikan efek penurunan viabilitas sel yang signifikan. Kedua penelitian ini dilatarbelakangi dengan mekanisme apoptosis yaitu mitchondrial pathway. Hederagenin meregulasi secara langsung p53 pada sel kanker kepala dan leher serta menekan jalur transkripsi gen antioksidan sehingga Nrf-2 tidak dihasilkan. Selanjutnya, p53 akan mengaktivasi protein pro apoptosis (BAX). Kemudian pada DPP-23, memiliki mekanisme yang hampir sama dengan hederagenin, namun pada DPP-23, agen pendeplesi GSH akan menekan jalur Nrf-2ARE sehingga produksi ROS akan meningkat dan produksi GSH menurun. Dengan adanya kondisi tersebut, p53 akan aktif dan mengaktivasi protein pro apoptosis (BAX dan PUMA).

Selanjutnya pada tipe sel kanker payudara, efektivitas agen pendeplesi GSH 
Tabel 3. Kemampuan Sitotoksik Kombinasi Cisplatin dan Agen Pendeplesi GSH (diadaptasi dari Benedetti et al (2011); Deng et al (2019); Jia et al (2018); Kim et al (2016); Kim et al (2017); Li, Yin, et al (2016); Li, Zhan, et al (2016); Liu et al (2019); Roh et al (2017); Zhang et al (2013))

\begin{tabular}{|c|c|c|c|c|c|c|}
\hline \multirow[t]{2}{*}{ Jenis Sel } & \multirow{2}{*}{$\begin{array}{l}\text { Agen } \\
\text { Pendeplesi } \\
\text { GSH }\end{array}$} & \multicolumn{2}{|c|}{ Konsentrasi kombinasi } & \multirow{2}{*}{$\begin{array}{c}\text { Viabilitassel } \\
+ \\
\text { cisplatin }(\%)\end{array}$} & \multirow{2}{*}{$\begin{array}{c}\text { Viabilitassel } \\
+ \\
\text { kombinasi }(\%)\end{array}$} & \multirow{2}{*}{$\begin{array}{c}\text { Selisih } \\
\text { Penurunan } \\
\text { viabilitas } \\
(\%)\end{array}$} \\
\hline & & $\begin{array}{c}\text { Cisplatin } \\
(\mu \mathrm{M})\end{array}$ & $\begin{array}{c}\text { GSH } \\
\text { Depletion } \\
(\mu \mathrm{M})\end{array}$ & & & \\
\hline \multirow{2}{*}{$\begin{array}{l}\text { Sel Kanker } \\
\text { Saluran } \\
\text { Empedu }\end{array}$} & $\mathrm{BSO}$ & 4 & 50 & 80 & 44 & 36 \\
\hline & PEITC & 4 & 10 & 70 & 55 & 15 \\
\hline $\begin{array}{l}\text { Sel Kanker } \\
\text { Pencernaan }\end{array}$ & $\alpha$-hederin & 4 & 10 & 75 & 10 & 65 \\
\hline \multirow{2}{*}{$\begin{array}{l}\text { Sel Kanker } \\
\text { Payudara }\end{array}$} & MCL & 10 & 5 & 75 & 55 & 20 \\
\hline & $\begin{array}{l}\text { Ekstrak } \\
\text { fucoidan }\end{array}$ & 5 & 200 & 67,1 & 47,6 & 19,5 \\
\hline $\begin{array}{l}\text { Sel Kanker } \\
\text { Ovarium }\end{array}$ & $\mathrm{BSO}$ & 10 & 500 & 86 & 55 & 31 \\
\hline \multirow{3}{*}{$\begin{array}{l}\text { Sel Kanker } \\
\text { Kepala dan } \\
\text { Leher* }\end{array}$} & Hederagenin & - & 10 & 100 & 70 & 30 \\
\hline & DPP-23 & - & 5 & 100 & 15 & 85 \\
\hline & Artesunat & - & 5 & 100 & 30 & 70 \\
\hline
\end{tabular}

dilakukan dengan menggunakan micheliolide dan ekstrak fucoidan. Berdasarkan penelitian Jia et al (2012) dan Zhang et al (2012), pada penggunaan senyawa fucoidan, mekanisme penurunan GSH menggunakan jalur Extracellular Regulated Kinase (ERK). Fucoidan akan mengaktivasi jalur ERK yang selanjutnya ERK akan beraktivitas pada mitokondria sel dengan memodulasi protein Bcl-2 dan akan mempengaruhi siklus sel baik proses transkripsi maupun translokasi sel hingga terjadi apoptosis. Kemudian pada senyawa micheliolide juga memiliki mekanisme yang sama dengan fucoidan yaitu melalui jalur ERK dan kemudian akan memengaruhi salah satu faktor transkripsi sel (KLF-4) sehingga dapat memicu apoptosis sel kanker payudara.

\section{Aktivitas Sitotoksik Kombinasi Cisplatin dan Agen Pendeplesi GSH beserta Mekanisme Apoptosisnya.}

Telah dipaparkan data terkait kemampuan aktivitas sitotoksik beserta konsentrasi yang digunakan (Tabel 3). Studi yang dilakukan Benedetti et al (2011) terhadap sel kanker ovarium, data yang disajikan menunjukan peningkatan apoptosis sebesar $36 \%$ dari persentase semula. Penurunan nilai apoptosis ini terlihat adanya interaksi dengan tingkat GSH sel. Penggunaan BSO sebagai agen pendeplesi GSH berlanjut hingga pada penelitian Li, Yin, et al (2016) melakukan penelitian terhadap pengaruh penggunaan BSO pada cisplatin terhadap sel kanker saluran empedu. Sel yang digunakan adalah sel GBC-SD. Hasil yang diperoleh menunjukkan penurunan viabilitas sel yang lebih drastis dari penelitian Benedetti et al (2011) sebelumnya yang dilakukan terhadap sel kanker ovarium, yaitu sebesar $31 \%$. Mekanisme apoptosis yang timbul adalah melalui penekanan jalur transkripsi STAT 3 yang disebabkan peningkatan produksi ROS sehingga STAT 3 akan terglutationilasi dan aktivitas STAT 3 akan menurun. STAT 3 adalah protein yang mengatur aktivitas protein anti-apoptosis (Bcl-2 dan Mcl-1). Dengan demikian, aktivitas proteinanti-apoptosis akan menurun.

Selanjutnya pada penelitian $\mathrm{Li}$, Zhan, et al (2016) menggunakan phenylethyl isothiocyanate (PEITC), menyatakan jumlah persentase viabilitas sel GBC-SD setelah dilakukan kombinasi menjadi menurun sangat drastis hingga $15 \%$. Mekanisme apoptosis sel diawali dengan menekan angka GSH sel dan menurunkan rasio GSH/GSSG. Selanjutnya, glutationilasi protein mcl-1 akan meningkat 
dan menyebabkan proteosomal sel kanker menjadi terdegradasi. Adanya degradasi proteosomal sel ini menyebabkan kanker akan mengalami apoptosis.

Sitotoksisitas suatu agen kemoterapi dapat didasarkan pada nilai $\mathrm{IC}_{50}$ dan nilai persentase viabilitas. Semakin rendah nilai viabilitas suatu sel kanker, maka senyawa dapat dikatakan semakin poten. Tabel 3 menggambarkan perbandingan nilai viabilitas sel cisplatin tunggal dengan viabilitas hasil kombinasi cisplatin dengan agen pendeplesi GSH, potensi masing-masing kombinasi didasarkan pada besar selisih persentase viabilitas sel. Namun, urutan tingkat keefektifan untuk seluruh sel kanker tidak dapat diberikan karena perlakuan yang diterima dan konsentrasi yang ditambahkan tiap literatur berbeda-beda. Dengan adanya penurunan nilai viabilitas yang signifikan di masing-masing jenis sel kanker, resistensi sel kanker terhadap cisplatin dapat dicegah, sehingga secara langsung hal ini juga dapat mencegah terjadinya efek samping utama penggunaan cisplatin, yaitu nefrotoksisitas (gangguan ginjal).

Pengaruh agen pendeplesi GSH terhadap nefrotoksisitas penggunaan cisplatin juga telah diteliti pada penelitian sebelumnya. Menurut Elkhoely \& Rehab Kamel (2017), pada penelitian yang menggunakan agen pendeplesi GSH terhadap angka nefrotoksisitas yang diinduksi oleh cisplatin secara invivo pada tikus, dihasilkan bahwa agen pendeplesi GSH mengurangi adanya nefrotoksisitas cisplatin melalui peningkatan kadar antioksidan dan penghambatan apoptosis melalui jalur sinyal p53. Penurunan angka nefrotoksisitas didasarkan pada pengukuran marker fungsi ginjal tikus yang menjelaskan dengan penambahan agen pendeplesi dapat menurunkan nilai kreatinin secara signifikan sebesar 50,5\% (50 mg/kg) dan 70,2\% (100 $\mathrm{mg} / \mathrm{kg}$ ) dibandingkan dengan kelompok tikus yang hanya diberi perlakuan cisplatin tunggal.

\section{KESIMPULAN}

Berdasarkan hasil penelitian, dapat disimpulkan bahwa kombinasi cisplatin dengan agen pendeplesi GSH dapat menurunkan persentase viabilitas di beberapa jenis sel kanker dibandingkan pengobatan dengan cisplatin tunggal. Adanya penurunan nilai viabilitas ini mengakibatkan kombinasi cisplatin dengan agen pendeplesi GSH bisa meningkatkan sitotoksisitas sel kanker secara invitro. Hal lebih lanjut berkaitan dengan efek samping utama juga telah diteliti bahwa kombinasi cisplatin dan agen pendeplesi GSH mampu menurunkan efek samping nefrotoksik penggunaan cisplatin. Akan tetapi, urutan tingkat keefektifan seluruh sel tidak dapat dilakukan karena perlakuan sel dan konsentrasi yang ditambahkan tiap literatur berbeda-beda

\section{Daftar Pustaka}

Benedetti B.T., Peterson E.J., Kabolizadeh P., Martínez A., Kipping R. and Farrell N.P., 2011, Effects of noncovalent platinum drug-protein interactions on drug efficacy: use of fluorescent conjugates as probes for drug metabolism., Molecular pharmaceutics, 8 (3), 940-948.

Chan S., Wang R., Man K., Nicholls J., Li H., Sun H. and Chan G.C.-F., 2019, A Novel Synthetic Compound, Bismuth Zinc Citrate, Could Potentially Reduce Cisplatin-Induced Toxicity Without Compromising the Anticancer Effect Through Enhanced Expression of Antioxidant Protein, Translational Oncology, 12 (5), 788-799.

Dasari S. and Bernard Tchounwou P., 2014, Cisplatin in cancer therapy: Molecular 
Mechanisms of Action, European Journal of Pharmacology, 740, 364-378.

Deng H., Ma J., Liu Y., He P. and Dong W., 2019, Combining $\alpha$-Hederin with cisplatin increases the apoptosis of gastric cancer in vivo and in vitro via mitochondrial related apoptosis pathway, Biomedicine \& Pharmacotherapy, 120, 109477.

Elkhoely, A. and Rehab Kamel., 2017, Diallyl sulfide alleviates cisplatin-induced nephrotoxicity in Rats via suppressing NF- $\kappa \mathrm{B}$ downstream inflammatory proteins and p53/Puma signaling pathway, Clinical and Experimental Pharmacology and Physiology, $38(1), 42-49$

Florea A.M. and Büsselberg D., 2011, Cisplatin as an anti-tumor drug: Cellular mechanisms of activity, drug resistance and induced side effects, Cancers, 3 (1), 1351-1371.

Ghosh S., 2019, Cisplatin: The first metal based anticancer drug, Bioorganic Chemistry, 88 (2019), 102925.

Jia Y., Zhang C., Zhou L., Xu H., Shi Y. and Tong Z., 2015, Micheliolide overcomes KLF4mediated cisplatin resistance in breast cancer cells by downregulating glutathione., OncoTargets and therapy, 8, 2319-2327.

Komeda, S., 2019, Different Effects of Cisplatin and Transplatin on the Higher-Order Structure of DNA and Gene Expression, International Journal of Molecular Sciences, 21(34), 1-15.

Kim E.H., Baek S., Shin D., Lee J. and Roh J.-L., 2017, Hederagenin Induces Apoptosis in Cisplatin- Resistant Head and Neck Cancer Cells by Inhibiting the Nrf2-ARE Antioxidant Pathway., Oxidative medicine and cellular longevity, 2017, 5498908.

Kim E.H., Jang H. and Roh J.-L., 2016, A Novel Polyphenol Conjugate Sensitizes CisplatinResistant Head and Neck Cancer Cells to Cisplatin via Nrf2 Inhibition., Molecular cancer therapeutics, 15 (11), 2620-2629.

Li Q., Zhan M., Chen W., Zhao B., Yang K., Yang J., Yi J., Huang Q., Mohan M., Hou Z. and Wang J., 2016, Phenylethyl isothiocyanate reverses cisplatin resistance in biliary tract cancer cells via glutathionylation-dependent degradation of Mcl-1., Oncotarget, 7 (9), 10271-10282.

Li Q., Yin X., Wang W., Zhan M., Zhao B., Hou Z. and Wang J., 2016, The effects of buthionine sulfoximine on the proliferation and apoptosis of biliary tract cancer cells induced by cisplatin and gemcitabine., Oncology letters, 11 (1), 474-480.

Liu Y., Lei H., Ma J., Deng H., He P. and Dong W., 2019, $\alpha$-Hederin Increases The Apoptosis Of Cisplatin-Resistant Gastric Cancer Cells By Activating Mitochondrial Pathway In Vivo And Vitro., OncoTargets and therapy, 12, 8737-8750.

Oh Y.K., Yun J.H., Ark D.P., Oo E.Y. and Ang H.K., 2009, Apoptosis Inducing Activity of Fucoidan in HCT-15 Colon Carcinoma Cells, Biological and Pharmaceutical Bulletin, 32 (10), 1760-1764.

Roh J.-L., Kim E.H., Jang H. and Shin D., 2017, Nrf2 inhibition reverses the resistance of cisplatin- resistant head and neck cancer cells to artesunate-induced ferroptosis, Redox Biology, 11 (2017), 254- 262.

Sato, T. et al.,2004, Fas-Mediated Apoptosome Formation Is Dependent on Reactive Oxygen Species Derived from Mitochondrial Permeability Transition in Jurkat Cells, The Journal of Immunology, 173(1), 285-296. 
Shin S.Y., Lee J.M., Lee M.S., Koh D., Jung H., Lim Y. and Lee Y.H., 2014, Targeting cancer cells via the reactive oxygen species-mediated unfolded protein response with a novel synthetic polyphenol conjugate, Clinical Cancer Research, 20 (16), 4302-4313.

Shelly C.Lu, M.D., 2014, Glutathione Synthesis, NIH Public Access, 1830 (5), 3143-3153.

Tewari-Singh N., Agarwal C., Huang J., Day B.J., White C.W. and Agarwal R., 2011, Efficacy of glutathione in ameliorating sulfur mustard analog-induced toxicity in cultured skin epidermal cells and in SKH-1 mouse skin in vivo, Journal of Pharmacology and Experimental Therapeutics, 336 (2), 450-459.

Yuniastuti, 2010, Dasar Molekuler Glutation dan Perannya Sebagai Antioksidan. Semarang: Penerbit FMIPA UNNES.

Zhang Z., Teruya K., Yoshida T., Eto H. and Shirahata S., 2013, Fucoidan extract enhances the anti- cancer activity of chemotherapeutic agents in MDA-MB-231 and MCF-7 breast cancer cells, Marine Drugs, 11 (1), 81-98. 